\title{
вMJ Global Health The Al Hol camp in Northeast Syria: health and humanitarian challenges
}

\author{
Neil J. Saad (D) $1,2,3$
}

\begin{abstract}
To cite: Saad NJ. The Al Hol camp in Northeast Syria: health and humanitarian challenges. BMJ Global Health 2020;5:e002491. doi:10.1136/ bmjgh-2020-002491
\end{abstract}

Handling editor Seye Abimbola

Received 13 March 2020

Revised 16 June 2020

Accepted 18 June 2020
Check for updates

(C) Author(s) (or their employer(s)) 2020. Re-use permitted under CC BY-NC. No commercial re-use. See rights and permissions. Published by BMJ.

${ }^{1}$ Berlin School of Public Health, Charité - Universitätsmedizin Berlin, Berlin, Germany ${ }^{2}$ European Programme for Intervention Epidemiology Training, European Centre for Disease Prevention and Control, Solna, Sweden

${ }^{3}$ Department of Infectious Disease Epidemiology, Robert Koch Institute, Berlin, Germany

Correspondence to

Dr Neil J. Saad;

neil-jan.saad@charite.de

\section{INTRODUCTION}

With the world in the grip of COVID-19 pandemic other emergencies risk drifting to the back of people's minds. One longstanding emergency is the war and conflict in Syria, which has claimed at least 500000 lives and left an estimated 11 million people in need of humanitarian assistance. ${ }^{12}$ In the Northwest of the country, in the Idlib and Northern Aleppo governorates, four million people, of which two-thirds are displaced from other parts of Syria, are currently in the midst of a humanitarian crisis due to a military campaign by Syrian and Russian government forces. ${ }^{3}$ In the Northeast, the plight of many in detention and refugee or internally displaced people (IDP) camps appears forgotten. To compound this complex situation further, COVID-19 has now also arrived in Syria, including in the Northeast. At the time of writing, in Syria, 124 cases and 6 deaths have been reported. ${ }^{45}$ Here, I aim to describe the situation in one of the refugee/ IDP camps in Northeast Syria, the Al Hol camp, based on my experiences there from May to August 2019 as an epidemiologist with Médecins Sans Frontières (MSF), to raise awareness about the health and humanitarian situation.

\section{HISTORY OF THE AL HOL CAMP}

The Islamic State of Iraq and Syria (ISIS) occupied large parts of Syria and Iraq and terrorised hundreds of thousands of Iraqis and Syrians living under their occupation. A coalition emerged in September 2014 to uproot ISIS, with Kurdish and Iraqi forces slowly reclaiming lost territory in a drawn-out war. In March 2019, the last ISIS enclave, Baghouz, was overrun by Kurdish troops and the caliphate was declared defeated. ${ }^{67}$ During the retreat of ISIS and after the fall of the caliphate, refugee and IDP camps were established across the Northeast to shelter those who had recently lived under ISIS's control

\section{Summary box}

Al Hol camp is the largest refugee/internally displaced people camp in Northeast Syria. It currently contains approximately 65000 individuals, of which an estimated 10000 are foreign non-Iraqi nationals.

- The current situation for those living in the camp is untenable due to abhorrent living conditions and restriction on medical care or access to care.

- International humanitarian and human rights law should always be respected in the camp and foreign governments should not forget the plight of their own nationals in the camp.

or were perceived to be the partners, children and relatives of male ISIS members. Three of these camps, of which the largest is the $\mathrm{Al}$ Hol camp, also contained foreign nationals, including Europeans who joined ISIS.

The Al Hol camp, close to the Syria-Iraq border, was initially set up by the United Nations High Commissioner for Refugees during the 1991 Gulf war for approximately 15000 people and it expanded further during the US invasion of Iraq in the early 2000s. In 2018, the camp hosted roughly 10000 Iraqi refugees but this grew to approximately 73 000, between December 2018 and March 2019, largely surpassing the capacity, due to a mass influx of refugees and IDP. When I arrived in May 2019, an estimated 11000 of the 73000 were third-country nationals, defined as neither Syrian nor Iraqi, and over $94 \%$ were women and children. ${ }^{8}$

Between December 2018 and March 2019, the new arrivals to the camp were transported from the Deir Al-Zour area, which was previously controlled by ISIS, through a series of security screening points. At the screening points, all men of fighting age, including adolescents above 14-15 years, were separated from their families and imprisoned. Only, women and children were allowed passage to the camp. ${ }^{910}$ Generally, newcomers first stay at a reception area and remain there until allocated a shelter and being 
provided with documentation. However, the mass influx resulted in approximately 15000 people living in rub halls, large warehouse-style tents meant to store supplies and hundreds living in open air in the reception area, exposed to the cold-barren Syrian winter. Ultimately, the people living in the reception area and rub halls were allocated a shelter. Also, some of the men were released later and allowed to join their families in the camp. ${ }^{11} 12$

Currently, the camp is divided into three large parts based on the nationality/ethnicity; one part for Iraqis, one part for Syrians and one part, fenced off, for thirdcountry nationals, which includes Europeans, North Americans and Central Asians. ${ }^{8}$ It is controlled by the Syrian Democratic Forces (SDF), an alliance of militia which is dominated by the Kurdish People's Protection Forces, with services provided by several United Nations agencies and international non-governmental organisations (NGOs), including MSF. However, refugee/IDP camp is, in reality, a euphemistic term for the $\mathrm{Al} \mathrm{Hol}$ camp as severe movement restrictions are imposed and camp residents are not accorded the rights and dignity under international humanitarian and human rights law. ${ }^{13}$

\section{HEALTH SITUATION IN THE CAMP}

The initial health conditions of the people arriving in the camp between December 2018 and March 2019 were dire. Many of them were in need of healthcare; children suffered from malnutrition, people were wounded or suffering from illnesses, such as acute diarrhoea. At least 240 people, mostly children, had died during the long journey on the trucks or on arrival at the camp due to malnutrition and hypothermia as a result of the horrendous conditions and winter temperatures. ${ }^{14} 15$ Moreover, the vulnerable state of the people arriving, who had survived without sufficient food or medical care at the frontlines, was exacerbated by the displacement as, during the long journey, security measures were deemed more important than provision of healthcare. This rapid influx of vulnerable people led to a humanitarian crisis, with insufficient food, water, shelter or healthcare available. $^{1214}$

Several months on, during my time there from May to August 2019, camp residents continued to suffer from poor water and sanitary conditions. The minimum emergency standards set by Sphere ${ }^{16}$ for water, which are $15 \mathrm{~L}$ per person per day, were not met in the camp. Many residents had to survive with $10 \mathrm{~L}$ of water daily, a third below minimally required, after queuing for hours. Moreover, water quality was commonly not suitable for drinking, exacerbating diarrhoea and other waterborne diseases among camp inhabitants. Of the nearly 9000 consultations in camp health facilities, $50 \%$ were for acute diarrhoea, during the period of May to July 2019. ${ }^{17}$ To compound the complex health situation, a measles outbreak and malnutrition crisis plagued the camp. Moreover, mental health problems, such as depression, anxiety and post-traumatic stress disorder, due to the conflict, strife and ISIS occupation were not addressed for the majority of the residents, due to the paucity of mental health services available. Access to medical care, particularly in the evenings, was very difficult for camp inhabitants due to the movement restrictions imposed by camp authorities. It was commonplace for women to give birth in their tents and referrals to an outside referral hospital were complicated and sometimes denied, even for urgent medical cases.

The annex, the fenced off part of the camp, where third-country nationals (non-Syrian and non-Iraqi nationals) are confined has worse health and sanitary conditions than the other parts of the camp. The people in the annex are also subject to harsher movement restrictions and more regularly denied access to healthcare by camp authorities, the SDF, due to their perceived ISIS affiliation. ${ }^{13}$ There was no full-time permanent health structure in the annex but healthcare referrals outside of the annex to either health facilities located in other parts of the camp or to the referral hospital were commonly denied. Pregnant women in the annex so commonly gave birth in their tents that clean delivery kits were handed out because security services would refuse referrals. Inhabitants of the annex were initially given $3 \mathrm{~L}$ of water per person per day for both drinking and cleaning purposes, which is a negligible amount. Oftentimes the water was not clean, with worms or other debris floating in it. Furthermore, the annex is an environment solely composed of women and children (all third-country national men are imprisoned) and yet it lacked a single school or child-friendly space. ${ }^{13}$ In an environment with such desolate circumstances, it is difficult to imagine what will become of the camp residents in the future.

\section{RECENT EVENTS}

In the harsh conditions of the $\mathrm{Al} \mathrm{Hol} \mathrm{camp,} \mathrm{international}$ NGOs, United Nations agencies and local authorities worked towards improving people's living conditions and supporting their basic needs. The Turkish military operation in the Northeast Syria in October 2019 forced several NGOs to evacuate their international staff and halt the majority of activities due to the volatility and uncertainty of the situation. Since December 2019, health actors have slowly returned to the $\mathrm{Al} \mathrm{Hol} \mathrm{camp} \mathrm{with} \mathrm{some} \mathrm{healthcare}$ provision and essential services resuming in the camp. ${ }^{18}$ However, in January 2020, the United Nations Security Council decided to reduce the international border crossings in opposition-controlled territory, used for the delivery of humanitarian aid, from four to two, which further complicates humanitarian assistance. ${ }^{19} 20$ This precarious context is now further disrupted by COVID19. Medical services remain scarce and facilities are insufficiently equipped; for example the Kurdish authorities only have 150 ventilators for the entire Northeast Syria. ${ }^{21} 22$ 


\section{CONCLUSION}

Nine years on in the Syria conflict, the humanitarian crisis will only worsen further due the COVID-19 pandemic. Particularly problematic is the restriction on medical care and access to care for people within the Al Hol camp based on their perceived ISIS affiliation, which is unjust and immoral. No person should be denied essential and potentially life-saving care, regardless of their background, nationality, religion or perceived affiliation. ${ }^{13}$ While countries decide on the appropriate long-term answer, international humanitarian and human rights law should always be respected. Countries, including European ones, should take responsibility for their nationals in these camps rather than simply refusing to repatriate them. ${ }^{23}$ As long as national governments continue to grapple with the situation in the $\mathrm{Al} \mathrm{Hol} \mathrm{camp} \mathrm{and}$ some governments attempt to forget the plight of their nationals, people will continue to suffer and struggle for dignity and survival.

Acknowledgements I acknowledge support from the German Research Foundation (DFG) and the Open Access Publication Fund of CharitéUniversitätsmedizin Berlin.

Contributors NJS wrote the article.

Funding The author has not declared a specific grant for this research from any funding agency in the public, commercial or not-for-profit sectors.

Disclaimer It was not possible to include or name local authors for political and security reasons. The views expressed in this article are those of the author and do not necessarily reflect the views of the European Centre for Disease Prevention and Control, the Robert Koch Institute, Médecins Sans Frontières or CharitéUniversitätsmedizin Berlin.

Competing interests None declared.

Patient consent for publication Not required.

Provenance and peer review Not commissioned; externally peer reviewed.

Data availability statement There are no data in this work.

Open access This is an open access article distributed in accordance with the Creative Commons Attribution Non Commercial (CC BY-NC 4.0) license, which permits others to distribute, remix, adapt, build upon this work non-commercially, and license their derivative works on different terms, provided the original work is properly cited, appropriate credit is given, any changes made indicated, and the use is non-commercial. See: http://creativecommons.org/licenses/by-nc/4.0/.

Author note NJS worked as an epidemiologist for Médecins Sans Frontières for 2 years, including 3 months in 2019 in two refugee and internally displaced people camps in Northeast Syria. He is currently a member of Charité-Universitätsmedizin Berlin and an EPIET fellow at the Robert Koch Institute in Berlin, Germany.

ORCID iD

Neil J. Saad http://orcid.org/0000-0003-2106-9915

\section{REFERENCES}

1 United Nations Office for the Coordination of Humanitarian Affairs. Humanitarian update Syrian Arab Republic, 2020.

2 Syrian revolution nine years on: 586,100 persons killed and millions of Syrians displaced and injured, 2020. Available: http://www.syriahr. com/en/?p=157193 [Accessed 19 Apr 2020].
3 United Nations Office for the Coordination of Humanitarian Affairs. Syrian Arab Republic-Recent Developments in Nortwest SyriaFlash, 2020.

4 United Nations Office for the Coordination of Humanitarian Affairs. Syrian Arab Republic: COVID-19 humanitarian update No.10 2020;10.

5 Who coronavirus disease (COVID-19) Dashboard, 2020. Available: https://covid19.who.int/region/emro/country/sy [Accessed 6 Jun 2020].

6 International Crisis Group. Fighting Isis: the road to and beyond Raqqa, 2017.

7 Joint Statement on Behalf of the Global Coalition to Defeat ISIS on the First Anniversary of ISIS's Territorial Defeat, 2020. Available: https://www.state.gov/joint-statement-on-behalf-of-the-globalcoalition-to-defeat-isis-on-the-first-anniversary-of-isiss-territorialdefeat/ [Accessed 19 Apr 2020].

8 Syria: Humanitarian response in Al Hol Camp. Situation report No. 1. United nations office for the coordination of humanitarian Affairs, 2019. Available: https://reliefweb.int/report/syrian-arab-republic/ syria-humanitarian-response-al-hol-camp-situation-report-no-1-enar [Accessed 6 Mar 2020].

9 Security checks delaying urgent healthcare for Syrians fleeing Islamic state: un official, 2019. Available: https://www. thenewhumanitarian.org/news/2019/02/11/security-checksdelaying-urgent-healthcare-syrians-fleeing-islamic-state-un-official [Accessed 19 Apr 2020].

10 United Nations Office for the Coordination of Humanitarian Affairs. Syria: Humanitarian Response in the Al Hol Camp-Situation Report No. 4, 2019.

11 Women and children continue to suffer in northeast Syria's Al Hol camp, 2019. Available: https://www.msf.org/women-and-childrencontinue-suffer-northeast-syria\%E2\%80\%99s-al-hol-camp-syria [Accessed 19 Apr 2020].

12 UNICEF-supported facilitators work around the clock to provide lifesaving assistance in Al-Hol cAMP, 2019. Available: https://www. unicef.org/mena/stories/unicef-supported-facilitators-work-aroundclock-provide-lifesaving-assistance-al-hol-camp [Accessed $19 \mathrm{Apr}$ 2020].

13 Syria: Dire Conditions for ISIS Suspects' Families, 2019. Available: https://www.hrw.org/news/2019/07/23/syria-dire-conditions-isissuspects-families [Accessed 6 Mar 2020].

14 Al Hol camp at 'breaking point' as 12,000 women and children arrive in 48 hours, 2019. Available: https://www.rescue-uk.org/pressrelease/al-hol-camp-breaking-point-12000-women-and-childrenarrive-48-hours [Accessed 19 Apr 2020].

15 Statement by Mr. Paulo Sérgio Pinheiro, chair of the independent International Commission of inquiry on the Syrian Arab Republic at the 41st session of the un human rights Council, 2019. Available: https://reliefweb.int/report/syrian-arab-republic/statement-mr-paulos-rgio-pinheiro-chair-independent-international-2 [Accessed $19 \mathrm{Apr}$ 2020].

16 Sphere. The Sphere Handbook - Humanitarian Charter and Minimum Standards in Humanitarian Response, 2018.

17 United Nations Office for the Coordination of Humanitarian Affairs. Syria: Humanitarian Response in the Al Hol Camp - Situation Report No. 5, 2019.

18 World Health Organization. Health sector Bulletin December 2019 Syrian Arab Republic, 2019.

19 United Nations Security Council. United nations security Council resolution 2504, 2020.

20 WHO Warns of Pandemic's 'Catastrophic Impact' on Syria, 2020. Available: https://foreignpolicy.com/2020/05/01/who-warns-ofpandemics-catastrophic-impact-on-syria/ [Accessed 5 Jun 2020].

21 International Crisis Group. Virus Fears Spread at Camps for ISIS Families in Syria's North East, 2020.

22 Syria confirms first Covid-19 case amid fears of catastrophic spread, 2020. Available: https://www.theguardian.com/world/2020/mar/ 23/syria-confirms-first-covid-19-coronavirus-case-amid-fears-ofcatastrophic-spread [Accessed 19 Apr 2020].

23 International Crisis Group. Women and children first: Repatriating the Westerners affiliated with ISIS, 2019. 